\title{
Respon Fisiologi Sapi FH Laktasi dengan Substitusi Pakan Pelepah Sawit dengan Jumlah yang Berbeda
}

\author{
Physiology Respons of FH Cows Lactation with Oil Palm Frond as Feed Subtitution in different \\ Percentage
}

\author{
A. Ghiardien'1, B. P. Purwanto ${ }^{2}$ \& A. Atabany ${ }^{3}$ \\ 1) Mahasiswa Program Studi Ilmu Produksi dan Teknologi Peternakan, Sekolah Pascasarjana, Insitut \\ Pertanian Bogor; 2) Program Diploma, Institut Pertanian Bogor; 3) Departemen Ilmu Produksi dan Teknologi \\ Peternakan, Fakultas Peternakan, \\ Institut Pertanian Bogor \\ Jln. Agatis, Kampus IPB Dramaga Bogor 16680, Indonesia
}

\begin{abstract}
This study was done to determine milk production and its quality of FH cows fed oil palm frond (OPF) for 3 months in UPT of Livestock Breeding Station Kampar Riau.This research used Fresh OPF chopping with different percentage as feed substitution in dairy feed to see the physiological responses of dairy cattle. The feeding treatments were $100 \% \mathrm{EG}, 75 \% \mathrm{EG}+25 \% \mathrm{OPF}, 50 \% \mathrm{EG}+$ $50 \%$ OPF and $25 \%$ EG $+75 \%$ OPF. This research was designed by Latin Square Design (RBSL) and analyzed by ANOVA with physiological responses which is skin temperature, body temperture,rectal temperature, respiration, and heart rate as observed variables. The results showed that cage condition and environmental could potentially caused stress (THI : 68-90). chopping fresh OPF with different percentage subtitution did not significantly effect to physiological response except heart rate where the highest value is $75 \%$ OPF with $72,1 \pm 1,98$ beat/min compared with control, $25 \%$ and $50 \%$. Overall, OPF can be used as feed resourch subtitution because did not give a negative effect for physiological responses for dairy cattle.
\end{abstract}

Key words: dairy cattle, physiological responses, skin temperature, body temperture,rectal temperature, respiration, heart rate.

\section{PENDAHULUAN}

Sapi perah laktasi sangat sensitif terhadap stress panas. Mekanisme termoregulasi dalam menjaga keseimbangan termal pada sapi dapat menurunkan produksi susu (Collier et al. 1982; Shearer dan Beede 1990). Faktor lainnya seperti tahap laktasi dan kebutuhan reproduksi mempengaruhi toleransi panas pada sapi (Igono dan Johnson 1990). Metode yang dilakukan untuk mengevaluasi atau memprediksi pengaruh kondisi termal pada intake (asupan) dan tahap laktasi harus memperhitungkan sensitivitas hewan dan respon terhadap faktor lingkungan.

Pemeliharaan sapi perah pada kondisi iklim tropis dengan suhu dan kelembaban yang tinggi dapat menurunkan produktivitas ternak dan produksi susu (Amir 2010). Kebutuhan energi pada sapi perah laktasi ditentukan oleh kebutuhan untuk hidup pokok yang dipengaruhi oleh berat badan, sedangkan kebutuhan untuk produksi susu dipengaruhi oleh banyaknya susu yang disekresikan dan kadar lemak yang terkandung di dalam susu (Bath et al. 1985).

Ketersediaan sumber pakan menjadi salah satu kendala yang menghambat pengembangan kuantitas produksi sapi perah di Indonesia. Berbagai upaya mulai dilakukan, yaitu peningkatan penggunaan lahan hijauan dengan sistem bertingkat, pemanfaatan limbah pertanian sebagai sumber hijauan, dan penyediaan pakan alternatif lain yang dapat mengatasi ketersediaan pakan (Ramli et al. 2010).

Hasil samping/ limbah dari kelapa sawit berpotensi menjadi sumber pakan alternatif untuk mengembangkan usaha peternakan. Provinsi Riau memiliki luas areal perkebunan kelapa sawit terbesar di Indonesia. Luas areal perkebunan kelapa sawit di Riau mencapai 2.256.538 Ha pada tahun 2011 (Departemen Pertanian 2013).Tanaman kelapa sawit dapat menghasilkan 18-25 pelepah/pohon/ tahun (Lubis 1992) atau sekitar 10 ton kering/Ha/tahun (Purba dan Ginting 1997). Pemanfaatan limbah perkebunan sawit menjadi sangat potensial menjadi salah satu alternatif penyedia sumber pakan untuk ternak perah di Indonesia. Penelitian ini ditujukan untuk mempelajari respon fisiologis sapi perah FH terhadap pemberian pakan berupa pelepah sawit.

\section{MATERI DAN METODE}

Waktu dan Tempat Penelitian

Penelitian ini dilaksanakan pada bulan Desember 
2015 sampai Februari 2016. Lokasi penelitian dilaksanakan di UPT Balai Pembibitan Peternakan Kabupaten Kampar Provinsi Riau.

\section{Prosedur Penelitian}

Ternak sapi FH laktasi melalui tahapan penyesuaian terhadap perubahan pakan (pre-eliminary) selama dua minggu sebelum diberikan perlakuan. Tahap ini bertujuan untuk mengurangi pengaruh pakan yang diberikan selama perlakuan terhadap peubah yang diamati. Persiapan pemeliharaan meliputi pembersihan kandang, menentukan ternak sapi FH laktasi yang akan dijadikan sebagai ternak penelitian dan persiapan pakan. Pakan hijauan berupa daun pelepah sawit sebelum diberikan ke ternak dan dicacah menggunakan chopper.

Ternak yang digunakan adalah sapi FH laktasi pertama bulan kelima sebanyak 4 ekor ternak dengan estimasi umur 24-36 bulan yang berada di UPT Balai Pembibitan Peternakan Kabupaten Kampar Provinsi Riau dipelihara dan diberikan pakan hijauan rumput raja (RR) dan daun pelepah sawit (DPS) dengan konsentrasi berbeda $(A=R R$ 100\% sebagai kontrol, B = RR 75\% + DPS 25\%, $\mathrm{C}=\mathrm{RR} 50 \%+$ DPS $50 \%$ dan D $=$ RR 25\% + DPS 75\%) pada tiap-tiap perlakuan selama 21 hari, masa adaptasi pakan selama dua minggu (14 hari) yang dilanjutkan untuk pengumpulan data selama 7 hari terakhir.

Pemberian pakan sebanyak $\pm 3 \%$ dari perkiraan bobot hidup dan penghitungan kebutuhan gizi pakan mengacu pada petunjuk Nutrient Requirements of Dairy Cattle (NRC 2001). Rasio hijauan dan konsentrat adalah 60\% : 40\%. Konsentrat yang diberikan adalah ampas tahu. Pakan diberikan dua kali sehari yaitu pukul 08.00 dan 15.00 WIB. Pemberian air minum disediakan adlibitum.

\section{Peubah yang Diamati}

Peubah yang diamati terdiri atas respons fisiologis - Faktor lingkungan yang diukur meliputi suhu udara, kelembaban (RH), temperature Humidity Index (THI) lingkungan dan temperature Humidity Index (THI) kandang. Untuk pengamatan mikrolimat lingkungan, pengamatan perubahan dengan interval 30 menit selama 11 jam (pukul $06.30-17.30 \mathrm{WIB})$.

Respons fisiologis ternak sapi yang diukur adalah suhu permukaan kulit (Ts), suhu rektal (Tr), menghitung suhu tubuh $(\mathrm{Tb})$, frekuensi pernafasan $(\mathrm{Rr})$, denyut jantung (Hr). Pencatatan suhu permukaan kulit (Ts), suhu rektal (Tr), suhu tubuh $(\mathrm{Tb})$, frekuensi pernapasan $(\mathrm{Rr})$ dan denyut jantung (Hr) setiap hari pada pukul 06.00, 12.00 dan 18.00 WIB.

\section{Analisis Data}

Pengaruh perlakuan pemberian pakan daun pelepah sawit terhadap respon fisiologis sapi FH dianalisis menggunakan Rancangan Bujur Sangkar Latin. Perbedaan nilai rataan pada peubah yang diukur dari setiap perlakuan diketahui melalui uji perbandingan duncan.

Terdapat dua faktor dalam percobaan ini yaitu individu sapi dan perlakuan, sehingga digunakan Rancangan Bujur Sangkar Latin 4 X 4 berupa 4 ekor sapi FH laktasi dan 4 Perlakuan pakan:

A (100\% hijauan rumput + konsentrat) sebagai kontrol
B (75\% rumput $+25 \%$ daun pelepah sawit + konsentrat $)$

C (50\% rumput $+50 \%$ daun pelepah sawit + konsentrat $)$

D $(25 \%$ rumput $+75 \%$ daun pelepah sawit + konsentrat $)$

Faktor lingkungan yang diukur meliputi suhu udara, kelembaban (RH), temperature Humidity Index (THI) lingkungan dan temperature Humidity Index (THI) kandang disusun secara deskriptif.

\section{HASIL DAN PEMBAHASAN}

Hasil penelitian kondisi Mikroklimat selama penelitian di UPT Balai Pembibitan Peternakan Kabupaten Kampar Provinsi Riau pada Tabel 1. Dalam pelaksanaan penelitian,hasil pengamatan kondisi mikroklimat di UPT Balai Pembibitan Peternakan Kabupaten Kampar Provinsi Riau, kondisi lingkungan selama penelitian dari pukul 6.3017.30 diperoleh suhu kandang berkisar $22-39^{\circ} \mathrm{C}$ dengan THI sekitar 71-88 berada diatas kondisi nyaman (zona termonetral) untuk sapi perah $\mathrm{FH}$ yang berkisar $13-25^{\circ} \mathrm{C}$ (Yani dan Purwanto 2006) dan suhu kritis pada sapi perah FH yaitu $27^{\circ} \mathrm{C}$ (Hadisusanto 2006). Menurut Bohmanova et al (2007), THI sapi perah yang nyaman dibawah 72 dengan kelembaban yang merupakan faktor pembatas dari stres panas di iklim lembab, sedangkan suhu udara kering adalah faktor pembatas stres panas di daerah beriklim kering. Dari Gambar 1 dan 2, fluktuasi suhu yang berbeda dari pagi hingga sore hari dimana suhu pada pagi hari baik di lingkungan maupun kandang berkisar $22{ }^{\circ} \mathrm{C}$ dan mengalami peningatan signifikan pada siang hari dan secara bertahap mengalami penurunan hingga sore hari pada kisaran suhu $26-28^{\circ} \mathrm{C}$.

Fluktuasi nilai THI juga mengalami perubahan yang sama dengan suhu yaitu pada pagi hari sekitar 70 kemudian meningkat mencapai 85 dan menurun mencapai 76. McDowell (1974) menyatakan bahwa untuk kehidupan dan produksinya, ternak memerlukan suhu lingkungan yang optimum, sedangkan hasil yang didapatkan berada pada kisaran stress ringan sampai dengan stress sedang dikarenakan suhu lingkungan yang tinggi menyebabkan suhu kandang pun tidak berbeda jauh. Pada pagi hari dengan suhu lingkungan dan kandang berkisar $22{ }^{\circ} \mathrm{C}$ dan THI 68 (THI <72) dikatakan bahwa dengan kondisi lingkungan ini sapi dalam kondisi nyaman dan tidak menyebabkan stress pada ternak (Chase, 2006). Pada siang hari pukul 10.3011.30 yang merupakan suhu dan THI maksimal berkisar 33-35 ${ }^{\circ} \mathrm{C}$ dan THI 84-85 (THI >72) dimana pada kondisi tersebut sapi masuk dalam kondisi stress sedang yang

Tabel 1 Kondisi mikroklimat lingkungan selama penelitian

\begin{tabular}{lc}
\hline Peubah & Rata-rata (Min-Max) \\
\hline Suhu lingkungan $\left({ }^{\circ} \mathrm{C}\right)$ & $30.44 \pm 2.90(22-39)$ \\
Suhu kandang $\left({ }^{\circ} \mathrm{C}\right)$ & $28.81 \pm 2.21(22-34)$ \\
Kelembaban lingkungan $(\%)$ & $79.65 \pm 10.12(54-92)$ \\
Kelembaban kandang $(\%)$ & $80.17 \pm 7.23(63-92)$ \\
Temperature Humidity Index & $82.51 \pm 3.17(71.30-92.00)$ \\
(THI) lingkungan & \\
$\begin{array}{l}\text { Temperature Humidity Index } \\
\text { (THI) kandang }\end{array}$ & $80.32 \pm 2.10(71.30-88.60)$ \\
\hline
\end{tabular}




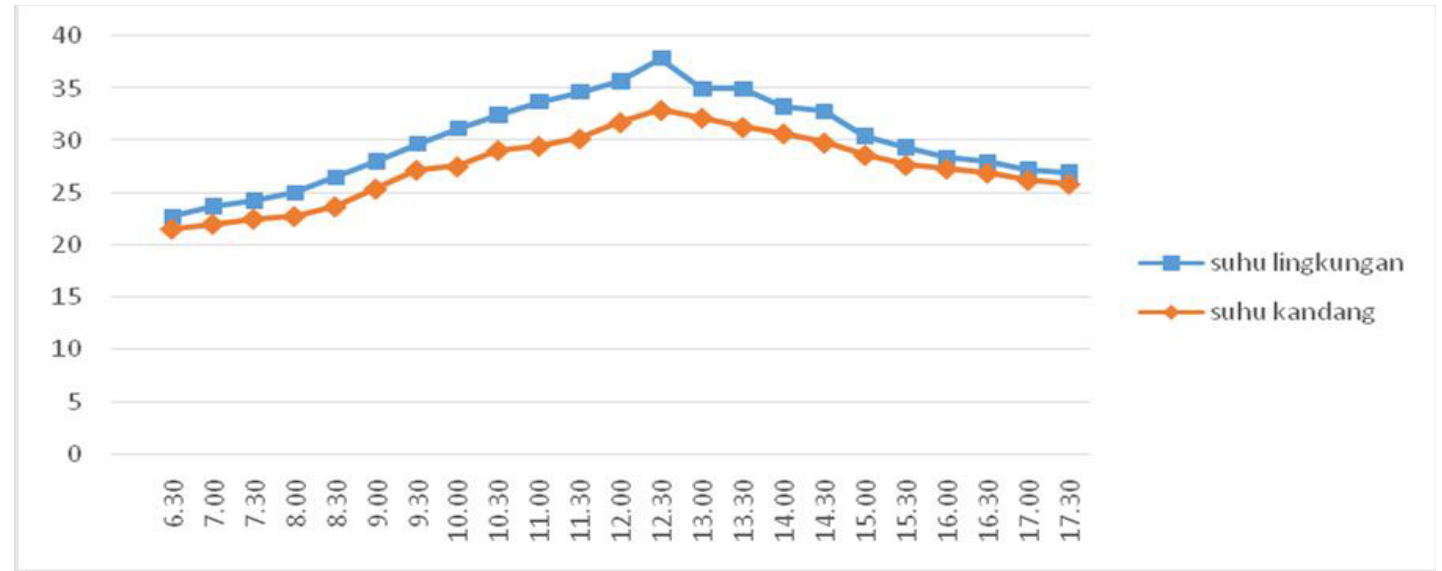

Gambar 1 Kondisi suhu lingkungan ( $)$ dan suhu kandang (ם)

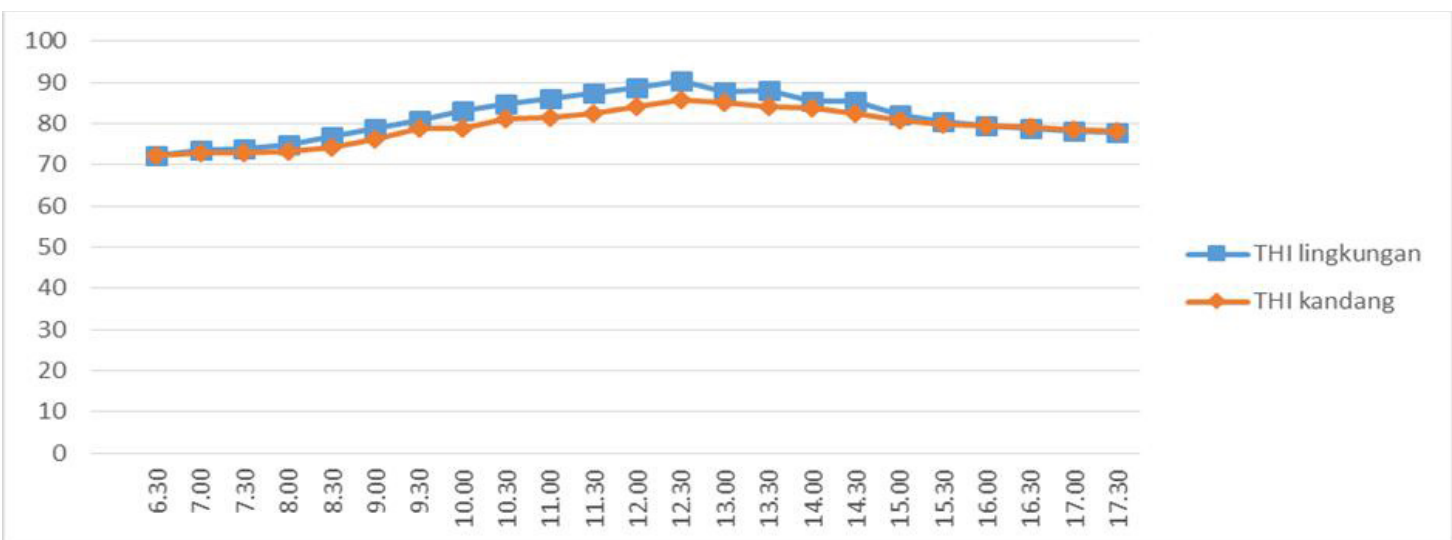

Gambar 2 Nilai THI Lingkungan ( $\bullet$ ) dan THI Kandang (ם)

dapat menyebabkan peningkatan produksi saliva serta laju pernafasan, dan minum akan meningkat serta meningkatnya suhu tubuh oleh karena itu pada kondisi lingkungan panas, ternak biasanya lebih selektif mengurangi pakan hijauan, relatif memilih konsentrat sebagi upaya mengurangi suhu inti tubuh melalui pengurangan produksi panas dari fermentasi, pencernaan dan proses metabolisme lainnya (Beede dan Collier 1986; Chase 2006).

Berdasarkan kondisi Mikroklimat berupa suhu, kelembaban dan Temperature Humidity Index (THI) dapat diketahui Sapi FH yang dipelihara di UPT Balai Pembibitan Peternakan Kabupaten Kampar mengalami cekaman/stress panas. Pengaruh yang timbul pada sapi FH yang terkena cekaman/stress panas adalah 1) penurunan nafsu makan; 2) peningkatan konsumsi minum; 3) penurunan metabolisme dan peningktan katabolisme; 4) peningkatan pelepasan panas melalui penguapan; 5) penurunan konsentrasi hormon dalam darah; 6) peningkatan temperatur tubuh, respirasi dan denyut jantung; dan 7) perubahan tingkah laku, meningkatnya intensitas berteduh sapi (Rejeb et al. 2012; Amstrong 1994).

\section{Respon Fisiologis}

Kondisi fisiologi ternak dapat diukur melalui laju pernafasan dan suhu rektal,suhu permukaan tubuh, suhu tubuh. Faktor-faktor yang mempengaruhi kondisi fisiologi ternak adalah suhu, kelembaban, konsumsi pakan, umur, aktivitas otot, kebuntingan dan stress (Purwanto et.al 1995).
Hasil pengukuran respon fisiologis ternak yang diberi perlakuan subtitusi pada saat penelitian dapat dilihat pada Tabel 2.

Suhu Rektal, Suhu Permukaan Tubuh dan Suhu Tubuh

Hasil penelitian ini menjelaskan bahwa jumlah subtitusi pelepah sawit yang berbeda di dalam pakan ternak sapi perah selama penelitian tidak berpengaruh nyata terhadap suhu rektal, suhu permukaan tubuh dan suhu tubuh sapi perah $(p>0.05)$. Hal ini disebabkan karena perlakuan pemberian subtitusi pelepah sawit tidak memberi pengaruh besar. Fluktuasi perubahan kondisi mikroklimat lingkungan berdampak pada respon fisiologis ternak secara umum

. Mekanisme termoregulasi atau pengaturan keseimbangan panas berjalan pada ternak terjadi secara baik (Igono et al. 1990).

Suhu rektal selama perlakuan pemberian pelepah sawit dengan persentase yang berbeda dimulai pada pagi hari hingga sore hari selama empat periode perlakuan berkisar antara 38-39 ${ }^{\circ} \mathrm{C}$. Menurut Smith dan Mangkoewidjojo (1988), suhu rektal sapi berkisar antara $38-39{ }^{\circ} \mathrm{C}$ (rata-rata $38.6^{\circ} \mathrm{C}$ ). Suhu rektal ternak yang berumur di atas satu tahun berkisar antara $37.8-39.2{ }^{\circ} \mathrm{C}$ (De Rensis dan Scaramuzzi 2003). Berdasarkan data tersebut, suhu rektal ternak masih berada dalam kondisi normal walaupun diberikan perlakuan jumlah substitusi pakan pelepah sawit yang berbeda. Tabel 3 menunjukkan bahwa perubahan suhu rektal mengikuti fluktuasi perubahan suhu lingkungan. Pada siang hari, suhu 
Tabel 2 Respon fisiologis ternak sapi perah FH selama penelitian

\begin{tabular}{lcccc}
\hline Keterangan & \multicolumn{4}{c}{ Jumlah pemberian pelepah sawit (\%) di dalam pakan } \\
\cline { 2 - 5 } & $0 \%$ & $25 \%$ & $50 \%$ & $75 \%$ \\
\hline Suhu rektal & $37.70 \pm 0.55$ & $38.02 \pm 0.63$ & $37.69 \pm 0.56$ & $37.96 \pm 0.57$ \\
Suhu permukaan tubuh & $32.49 \pm 1.68$ & $31.43 \pm 0.96$ & $32.57 \pm 1.72$ & $32.21 \pm 1.36$ \\
Suhu tubuh & $37.83 \pm 0.58$ & $37.93 \pm 0.50$ & $37.79 \pm 0.59$ & $37.81 \pm 0.44$ \\
Respirasi & $42.86 \pm 8.35$ & $51.25+9.47$ & $43.81 \pm 9.67$ & $45.48 \pm 9.75$ \\
Denyut jantung & $66.05 \pm 3.00 \mathrm{~b}$ & $70.92 \pm 1.91 \mathrm{a}$ & $69.19 \pm 2.93 \mathrm{ab}$ & $72.15 \pm 1.98 \mathrm{a}$ \\
\hline
\end{tabular}

Keterangan : *) perlakuan berpengaruh nyata dengan tingkat kepercayaan $95 \%(\mathrm{P}<0.05)$; tn: perlakuan tidak berpengaruh nyata dengan tingkat kepercayan 95\% ( $\mathrm{P}>0.05)$; Superskrip ( $\mathrm{a}, \mathrm{ab}$ dan $\mathrm{b}$ ) pada baris yang sama dengan huruf yang sama menunjukkan tidak berbeda terhadap masing-masing perlakuan.

Tabel 3 Suhu rektal ternak sapi perah $\mathrm{FH}\left({ }^{\circ} \mathrm{C}\right)$ selama penelitian

\begin{tabular}{lccccc}
\hline Data harian & \multicolumn{3}{c}{ Jumlah pemberian pelepah sawit (\%) di dalam hijauan } & \multirow{2}{*}{ Rerata } \\
\cline { 2 - 5 } & $0 \%$ & $25 \%$ & $50 \%$ & $75 \%$ & $37.27 \pm 0.42$ \\
\hline Pagi (06.00) & $37.17 \pm 0.46$ & $37.41 \pm 0.57$ & $37.13 \pm 0.25$ & $37.35 \pm 0.47$ & $38.18 \pm 0.40$ \\
Siang (12.00) & $37.99 \pm 0.48$ & $38.32 \pm 0.45$ & $38.08 \pm 0.43$ & $38.34 \pm 0.27$ & $38.10 \pm 0.39$ \\
Sore (18.00) & $37.95 \pm 0.31$ & $38.34 \pm 0.40$ & $37.93 \pm 0.43$ & $38.20 \pm 0.39$ \\
Rerata & $37.70 \pm 0.46$ & $38.02 \pm 0.53$ & $37.71 \pm 0.51$ & $37.87 \pm 0.50$ \\
\hline
\end{tabular}

Tabel 4 Suhu permukaan tubuh sapi perah $\mathrm{FH}\left({ }^{\circ} \mathrm{C}\right)$ selama penelitian

\begin{tabular}{lccccc}
\hline Data harian & \multicolumn{3}{c}{ Jumlah pemberian pelepah sawit (\%) di dalam pakan } & \multicolumn{2}{c}{ Rerata } \\
\cline { 2 - 5 } & $0 \%$ & $25 \%$ & $50 \%$ & $35 \%$ & $30.62 \pm 0.09$ \\
\hline Pagi (06.00) & $30.63 \pm 0.80$ & $30.51 \pm 0.24$ & $30.63 \pm 0.63$ & $30.71 \pm 0.34$ & $33.39 \pm 0.70$ \\
Siang (12.00) & $33.90 \pm 0.32$ & $32.42 \pm 0.95$ & $33.90 \pm 0.18$ & $33.35 \pm 0.84$ & $32.51 \pm 0.81$ \\
Sore (18.00) & $32.94 \pm 0.30$ & $31.36 \pm 1.30$ & $33.19 \pm 0.36$ & $32.56 \pm 1.22$ & \\
Rerata & $32.49 \pm 1.68$ & $31.43 \pm 0.96$ & $32.57 \pm 1.72$ & $32.21 \pm 1.36$ \\
\hline
\end{tabular}

rektal lebih tinggi $\left(38.18 \pm 0.40^{\circ} \mathrm{C}\right)$ dibandingkan pada pagi $\left(37.27 \pm 0.42{ }^{\circ} \mathrm{C}\right)$ dan sore hari $\left(38.10 \pm 0.39^{\circ} \mathrm{C}\right)$. Hal ini disebabkan karena cekaman panas akibat perubahan suhu terjadi pada siang hari yang mengakibatkan peningkatan suhu rektal.

Suhu permukaan tubuh ternak pada penelitian ini berkisar antara $30-33{ }^{\circ} \mathrm{C}$ (Tabel 4). Pada umumnya, pola perubahan suhu permukaan tubuh ternak sapi perah $\mathrm{FH}$ seirama dengan tingkat panas yang diterima dari kondisi lingkungan. Kulit merupakan bagian terluar penerima panas yang suhunya secara langsung mengikuti perubahan suhu lingkungan (Swenson 1997). Kenaikan nilai laju respirasi yang terjadi merupakan reaksi sapi terhadap perubahan suhu lingkungannya dan berdampak terhadap naiknya produksi panas di dalam tubuh ternak dan membantu hewan meningkatkan kehilangan panas tubuh melalui saluran pernapasan (Purwanto et al. 1995).

Suhu tubuh terdiri atas suhu rektal dan suhu permukaan tubuh. Substitusi pelepah sawit dalam jumlah yang berbeda tidak berpengaruh nyata terhadap suhu tubuh $(\mathrm{P}>0.05)$. Tabel 5 menunjukkan perubahan suhu tubuh mulai dari pukul $06.00(37.23 \pm 0.12)$, lalu meningkat pada pukul $12.00(38.12 \pm 0.08)$ dan pada pukul 18.00 yaitu $(38.17 \pm 0.07)$. Suhu lingkungan penelitian pada sore hari berkisar antara $26-27{ }^{\circ} \mathrm{C}$ dan THI berkisar $76-78$ yang berada pada cekaman stress ringan. Suhu tubuh meningkat seiring dengan meningkatnya suhu lingkungan, sehingga tubuh menyesuaikan dengan kondisi lingkungan dan sapi perah akan menyesuaikan dengan mencari naungan, meningkatkan laju respirasi, dan pelebaran pembuluh darah (Bouraoui et al. 2002; Moran 2005; Chase 2006).

\section{Denyut Jantung}

Tabel 6 menunjukkan bahwa substitusi pelepah sawit dalam jumlah yang berbeda berpengaruh nyata terhadap denyut jantung sapi perah $(\mathrm{P}<0.05)$. Denyut jantung yang didapatkan pada substitusi $75 \%$ pelepah sawit di dalam hijauan (72.15 $\pm 1.98 \mathrm{kali} /$ menit $)$ lebih besar dibandingkan dengan kontrol (66.05 $\pm 3.00 \mathrm{kali} /$ menit), 25\% (70.92 $\pm 1.91 \mathrm{kali} /$ menit $)$ dan 50\% (69.26 $\pm 2.93 \mathrm{kali} / \mathrm{menit})$ tingginya frekuensi deyut nadi, kemungkinan disebabkan tingginya beban panas dari dalam dan luar tubuh. Pakan dengan kualitas rendah menyebabkan proses fermentasi di dalam rumen lebih lambat, sehingga panas yang dihasilkan dari energi untuk proses metabolisme tubuh lebih kecil dan berpengaruh terhadap peningkatan denyut nadi, dikarenakan salah satu fungsi protein adalah untuk menyediakan energi bagi proses metabolisme tubuh (Sudono,1999).

Denyut jantung sapi perah FH pada Tabel 6 menunjukkan pada siang hari $(70.68 \pm 3.49 \mathrm{kali} /$ menit $)$ lebih tinggi dibandingkan dengan pagi hari $(69.45 \pm 2.57$ kali/menit) dan sore hari (68.66 $\pm 3.78 \mathrm{kali} / \mathrm{menit})$. Hal ini disebabkan suhu lingkungan yang panas di siang hari menyebabkan sapi mengalami cekaman panas . Menurut Purwanto et al. (1995) reaksi mekanisme homeostasis 
Tabel 5 Suhu tubuh sapi perah $\mathrm{FH}\left({ }^{\circ} \mathrm{C}\right)$ selama penelitian

\begin{tabular}{lccccc}
\hline Data harian & \multicolumn{3}{c}{ Jumlah pemberian pelepah sawit (\%) di dalam pakan } & \multirow{2}{*}{ Rerata } \\
\cline { 2 - 5 } & $0 \%$ & $25 \%$ & $50 \%$ & $75 \%$ & $37.23 \pm 0.12$ \\
\hline Pagi (06.00) & $37.16 \pm 0.48$ & $37.36 \pm 0.35$ & $37.11 \pm 0.32$ & $37.31 \pm 0.11$ & $38.12 \pm 0.08$ \\
Siang (12.00) & $38.19 \pm 0.47$ & $38.17 \pm 0.36$ & $38.12 \pm 0.30$ & $38.01 \pm 0.25$ & $38.17 \pm 0.07$ \\
Sore (18.00) & $38.14 \pm 0.18$ & $38.27 \pm 0.14$ & $38.15 \pm 0.35$ & $38.12 \pm 0.11$ & \\
Rerata & $37.83 \pm 0.58$ & $37.93 \pm 0.50$ & $37.79 \pm 0.59$ & $37.81 \pm 0.44$ & \\
\hline
\end{tabular}

Tabel 6 Denyut jantung (kali/menit) ternak sapi perah FH selama penelitian

\begin{tabular}{lccccc}
\hline Data harian & \multicolumn{3}{c}{ Jumlah pemberian pelepah sawit (\%) di dalam pakan } & \multicolumn{2}{c}{ Rerata } \\
\cline { 2 - 6 } & $0 \%$ & $25 \%$ & $50 \%$ & $75 \%$ & $69.45 \pm 2.57$ \\
\hline Pagi (06.00) & $66.89 \pm 0.84$ & $71.25 \pm 2.22$ & $68.18 \pm 1.13$ & $71.46 \pm 2.33$ & $70.68 \pm 3.49$ \\
Siang (12.00) & $66.93 \pm 3.43$ & $71.43 \pm 2.14$ & $70.68 \pm 3.14$ & $73.68 \pm 1.80$ & $68.66 \pm 3.78$ \\
Sore (18.00) & $64.32 \pm 3.81$ & $70.07 \pm 1.55$ & $68.93 \pm 4.01$ & $71.32 \pm 1.00$ & \\
Rerata & $66.05 \pm 3.00$ & $70.92 \pm 1.91$ & $69.26 \pm 2.93$ & $72.15 \pm 1.98$ & \\
\hline
\end{tabular}

Tabel 7 Laju respirasi ternak sapi perah FH (kali/menit) selama penelitian

\begin{tabular}{lccccc}
\hline Data harian & \multicolumn{3}{c}{ Jumlah pemberian pelepah sawit (\%) di dalam pakan } & \multicolumn{2}{c}{ Rerata } \\
\cline { 2 - 5 } & $0 \%$ & $25 \%$ & $50 \%$ & $75 \%$ & $32.69 \pm 2.01$ \\
\hline Pagi (06.00) & $33.39 \pm 4.06$ & $32.41 \pm 0.99$ & $32.39 \pm 1.01$ & $32.68 \pm 0.88$ & $52.55 \pm 5.13$ \\
Siang (12.00) & $51.75 \pm 1.68$ & $49.96 \pm 10.19$ & $54.29 \pm 2.40$ & $54.21 \pm 1.31$ & $46.30 \pm 3.05$ \\
Sore (18.00) & $43.43 \pm 3.34$ & $45.45 \pm 1.69$ & $46.79 \pm 1.57$ & $49.54 \pm 1.96$ & \\
Rerata & $42.86 \pm 8.35$ & $42.61 \pm 9.47$ & $44.49 \pm 9.67$ & $45.48 \pm 9.75$ & \\
\hline
\end{tabular}

(termoregulasi) untuk mengurangi atau melepaskan panas yang diterima dari luar tubuh dan apabila terjadi peningkatan suhu udara maka diikuti dengan peningkatan denyut jantung yang merupakan mekanisme fisiologis ternak sehingga ternak berusaha mempercepat frekuensi denyut jantung untuk membuang panas.

\section{Laju Respirasi}

Tabel 7 menunjukkan hasil laju respirasi dengan rerata yang didapatkan berkisar antara 33-53 kali/menit. Nilai rerata ini masih dalam kisaran hasil penelitian Purwanto et al. (1993) yang memperoleh rerata respirasi pernafasan antara 25-65 kali/menit. Peningkatan frekuensi respirasi terjadi ketika ada peningkatan permintaan oksigen setelah beraktivitas, terpapar pada kondisi suhu lingkungan dan kelembaban relatif yang tinggi (Baret et al. 2010). Laju respirasi tertinggi berada pada siang hari (52.55 $\pm 5.13 \mathrm{kali} /$ menit) dibandingkan pada pagi hari $(32.69 \pm 2.01 \mathrm{kali} / \mathrm{menit})$ dan sore hari (46.30 $\pm 3.05 \mathrm{kali} /$ menit). Hal ini didukung oleh kondisi THI pada pagi hari kurang dari 72, menuju siang hari THI berada di atas 80 dan sore hari kembali menurun berkisar 76. Menurut Chase (2006), pada THI lebih dari 72 terjadi cekaman pada sapi, terutama pada siang hari dengan THI di antara 80-89 dengan level stress sedang, dimana terjadi reaksi seperti produksi saliva menurun, laju respirasi meningkat, konsumsi pakan menurun, konsumsi air naik, suhu tubuh pun meningkat yang dapat menyebabkan produksi susu dan reproduksi menurun.

Substitusi pelepah sawit segar yang telah dicacah dalam persentase yang berbeda dalam pakan ternak tidak berpengaruh nyata terhadap laju respirasi $(\mathrm{P}>0.05)$. Kenaikan nilai laju respirasi yang terjadi merupakan reaksi sapi terhadap perubahan suhu lingkungannya dan berdampak terhadap naiknya produksi panas di dalam tubuh ternak. Peningkatan respirasi pernafasan juga membantu hewan meningkatkan kehilangan panas tubuh melalui saluran pernapasan (Purwanto et al. 1993).

\section{KESIMPULAN}

Respon fisiologis (suhu tubuh, detak jantung, laju respirasi, suhu rektal kecuali detak jantung) tidak dipengaruhi oleh perlakuan perbedaan jumlah subtitusi pelepah sawit dan secara umum masih dalam kisaran normal. Respon fisiologis secara umum mengalami peningkatan dan penurunan mengikuti perubahan kondisi lingkungan dimana kondisi lingkungan selama penelitian cenderung panas dengan cekaman stress ringan sampai dengan sedang.

\section{DAFTAR PUSTAKA}

Amir A. 2010. Respon termoregulasi dan tingkah laku bernaung sapi perah dara peranakan Fries Holland pada energi ransum yang berbeda [tesis]. Bogor (ID): IPB.

Amstrong DV. 1994. Heat stress interaction with shade ang cooling. J Diary Sci. 77: 2044-2050.

Badan Standarisasi Nasional. 1998. Standar Nasional Indonesia 01-3141-1998: Susu Segar. Jakarta (ID). Departemen Perindustrian Indonesia.

Baret K, Brooks H, Boitano S, Barman S. 2010. Ganong's Review Of Medical Physiology. 23th Edition. California (US): McGraw Hill Co.

Bath DL, Foley, RC, Dickinson FN, Tucker HA. 1985. Dairy Cattle Principles, Practices, Problem and Profits. 
Philadelphia (US) : Lea and Febiger.

Beede DK, Collier RJ. 1986. Potential nutritional strategies for intensively managed cattle during thermal stress, J. Anim. Sci. 62 (1986) 543-554.

Bohmanova J, Misztal I, Cole, JB. 2007. Temperaturehumidity indices as indicators of milk production losses due to heat stress. J. Dairy Sci. 90 : 1947-1956. https:// www.aipl.arsusda.gov/publish/jds/2007/90_1947.pdf

Bouraoui R, Lahmar M, Majdoub A, Djemali M, Belyea R. 2002. The relationship of temperature-humidity index with milk production of dairy cows in a Mediterranean climate. Anim. Res. 51 (2002) 479-491.

BPS. 2014. Luas Tanaman Perkebunan Menurut Propinsi dan Jenis Tanaman. Jakarta (ID). Badan Pusat Statistik Indonesia.

Chase, LE. 2006. Climate Change Impacts on Dairy Cattle. Fact sheet, Climate Change and Agriculture: Promoting Practical and Profitable Responses. Online at http:// dbccc.onep.go.th/climate/attachments/article/105/ Climate\%20Change\%20Impacts\%20on\%20Dairy\%20 Cattle.pdf [15 april 2016].

Collier RJ, Beede DK, Thatcher WW, Israel LA, Wilcox CJ. 1982. Influences of environment and its modification on dairy animal health and production. J. Dairy Sci. 65:2213-2227.

Frandson RD. 1996. Anatomi dan Fisiologi Ternak. Yogyakarta: Gadjah Mada University Press.
Igono MO, Johnson HD. 1990.Physiological stress index of lactating dairy cows based on diurnal pattern of rectal temperature. J. Interdiscip. Cycle Res. 21, 303-320.

Lubis AU. 1992. Kelapa Sawit (Elaeis Guineensis. Jacq.) Di Indonesia. Pusat Penelitian Perkebunan MarihatBandar Kuala. Sumatera Utara.

Purba A. dan S. P. ginting. 1997. Integrasi Perkebunan Kelapa Sawit Dengan Ternak Ruminansia. Jurnal Penelitian Kelapa Sawit 5 (2) : 55-60.

Purwanto BP, Santoso AB, Murfi A. 1995. Fisiologi Lingkungan. Fakultas Peternakan. Institut Pertanian Bogor, Bogor (ID)

Purwanto BP, Matsumoto T, Nakamasu F, Ito T, Yamamoto S. 1993. Effect of standing and lying behaviours on heat production of dairy heifers differing in feed intake levels. AJAS. 6:271-274.

Shearer, JK, Beede DK. 1990. Thermoregulation and physiological responses of dairy cattle in hot weather. Agri-Practice 11: 5-17.

Swenson. 1997. Duke's Physology of Domestic Animal. Comstok Publishing Co. Lnc Pert Conectial(US). 